\title{
РАЗВИТИЕ МЕЖКУЛЬТУРНОГО ДИАЛОГА В ВУЗЕ
}

\section{THE DEVELOPMENT OF INTERCULTURAL DIALOGUE IN AN EDUCATIONAL INSTITUTION}

\section{O. Pinigina}

Summary: The article focuses on development of intercultural dialogue of Arctic state Institute of Culture and Arts as an important component of the educational policy of the university aimed at integration into the world educational and scientific space. The aspects of international activities that encourage students and teachers to participate in academic mobility programs and joint projects are described. The importance of foreign language proficiency and the ability to cross-cultural communication is emphasized. Focuses on individual-personal readiness for intercultural dialogue. Recommendations have been formulated for the construction of language training courses that ensure the effectiveness of mastering the practical skills of foreign-speaking communication.

Keywords: intercultural dialogue, international cooperation, foreign language communication, intercultural communication, mobility programs.

\section{Введение}

$\Pi$ роцессы интернационализации глубоко затронули систему высшего профессионального образования. И можно с уверенностью сказать, что в настоящее время активно формируется единое мировое образовательное пространство, в котором наблюдается рост студенческой и преподавательской мобильности, профессиональных и научных обменов, расширяются границы сотрудничества путем проведения совместных культурных мероприятий. Соответственно одним из основных условий успешного развития международных контактов является разработка программ обучения иностранному языку и межкультурной коммуникации, расширение модульных курсов овладения иноязычным общением.

Арктический государственный институт культуры и искусства (АГИКИ) ставит перед собой большие цели в плане развития международного сотрудничества. Так, с 2003 года институт является членом международного Университета Арктики и активно проводит в жизнь программу студенческой мобильности «Север Северу» (North2North). По международным программам обмена студенты института регулярно проходят обучение в зарубежных вузах. Для того, чтобы программы мобильности успешно развивались, институтом предусматривается увеличение количества преподавателей, владеющих

\author{
Пинигина Ольга Николаевна \\ Арктический государственный институт \\ культуры и искусств \\ cddo@agiki.ru
}

Аннотация: В статье рассматривается развитие межкультурного диалога в Арктическом институте культуры и искусств как важной составляющая образовательной политики вуза, направленной на интеграции в мировое образовательное и научное пространство. Описаны аспекты международной деятельности, способствующие вовлечению студентов и преподавателей к участию в программах академической мобильности и совместных проектах. Подчеркивается важность владения иностранными языками и способностью к межкультурной коммуникации. Фокусируется внимание на индивидуально-личностной готовности к межкультурному диалогу. Сформулированы рекомендации по построению учебных языковых курсов, обеспечивающих эффективность освоения практических навыков иноязычного общения.

Ключевые слова: межкультурный диалог, международное сотрудничество, иноязычное общение, межкультурная коммуникация, программы мобильности.

иностранными языками. Направленность на достижение таких серьезных целей подтверждает приверженность вуза интернационализации образования. Остановимся на этом понятии более подробно.

В научных публикациях исследователей, связанных с проблемами высшего образования, интернационализация понимается как объективный процесс устойчивого взаимодействия и взаимовлияния национальных систем высшего образования на основе общих целей и принципов, отвечающий потребностям мирового сообщества и отражающий прогрессивные тенденции нового столетия [1, С.6-7; 2, С.1-5]. Известно, что интернационализация, в первую очередь, предполагает создание такой культуры и климата внутри вуза, которые продвигают и поддерживают международное и межкультурное взаимопонимание.

Исходя из этого, основная задача института состоит в том, чтобы сохранять и развивать культурные ценности, препятствовать процессу распада культур на основе активного приобщения к лучшим образцам мировой и национальной культуры.

Такое понимание участия в процессе интернационализации легло в основу международной деятельности вуза, которая включает участие в программах студенческих обменов, стажировки преподавателей, участие в 
конкурсах и сетевых программах, выставках технического и художественного творчества. За последние годы возросло число совместных культурных мероприятий. В условиях расширяющихся международных коммуникаций такая ситуация естественна. Каждый вуз культурного профиля открыт для восприятия чужого культурного опыта и одновременно сам готов делиться с другими продуктами собственной культуры. Это обращение к культурам других народов принято называть «взаимодействием культур» или «межкультурной коммуникацией». Как справедливо отмечают исследователи, во взаимодействии якутских и иностранных студентов и преподавателей рождаются порой уникальные проекты, способствующие дальнейшему сплочению, стиранию границ, национальных различий [4, С.324-327\$ 5, С.236-238]. Рассказать о себе, о своей стране и культуре зарубежным партнерам студенты имеют возможность в рамках всероссийских, региональных, межвузовских мероприятий.

Так, в рамках международного проекта «Искусство Арктики-2017 «Кочующие свитки» получена поддержка Министерства образования и науки России в виде грантового вознаграждения для организации передвижных выставок по странам мира. Художники с помощью якутянки Ольги Монастыревой, проживающей в Бельгии, провели в городе Брюгге выставку якутских художников. И это была седьмая страна, увидевшая «Кочующие свитки». Авторами картин были художники-преподаватели института.

Большой интерес у зарубежных коллег вызвала работа Петровой Анны «Хантан хааннаах, кимтэн кииннээх.../ Откуда родом...», созданная на основе интерпретации архаичных символов и орнаментальных мотивов саха. Символические знаки, представленные в работе, были изображены на древних писаницах, которые, предположительно, создавали мигранты, прибывшие несколько тысячелетий назад на суровые земли севера.

В последнее время институт посетили участники Совета Правления Университета Арктики, представляющие ведущие вузы скандинавских стран (Норвегия, Швеция, Финляндия), США (Аляска) и Канады. Многие из них являются давними друзьями нашего вуза по опыту сотрудничества в рамках международной образовательной программы «Север-Северу» (North2North).

Привлекательным для зарубежных партнеров является Музей музыкальных инструментов народов Северной Азии, который посетили Брайн Роджерс, председатель правления, ректор университета Аляски (Фэрбэнкс, США); Ласси Лоннум - директор Арктического университета Норвегии (г. Тромсё); Питер Школьд, директор Арктического исследовательского центра (университет Умеа, Швеция); Ларс Куллеруд, президент университета Арктики (Норвегия); Пол Маркуссон из университета г.
Тромсё; Шила Даунер, вице-президент по вопросам финансирования, развития и взаимодействия, директор Мемориального университета Ньюфаундленда (Канада); Скотт Форест, главный специалист по связям с общественностью (Финляндия) и Росс Вирджиния, профессор и директор института Арктических исследований Дартмутского колледжа (США).

Экскурсию по Музею провела доцент кафедры искусствоведения Т.И. Игнатьева. Она рассказала гостям о коллекции музыкальных инструментов, собранных профессором Ю.И. Шейкиным в различных регионах Северной Азии. Среди экспозиций особый интерес представителей иностранных арктических вузов вызвали такие инструменты, как хантыйская угловая арфа торсапль-юх - уникальный и единственный в своем роде инструмент среди сибирских народов; охотничий манок на лося чомэль napm сургутских хантов, который представляет собой деревянные доски с зарубками; продолговатая мансийская цитро-лира санквылтап; удэгейская смычковая пиколютня дзюлианки; и многие другие орудия труда и охоты.

В сотрудничестве с Варшавским университетом институт начал активную работу в Международной зимней школе Чысхаана - Хранителя Холода. Одной из основных задач работы зимней школы является приобщение якутской молодежи к проблемам экологии, глобального потепления через исследовательские творческие проекты, участие в которых требует постоянного совершенствования умений иноязычного межкультурного общения. Примечательно то, что в школу с большим желанием приходят учащиеся близлежащих сел, так как здесь для них открыто широкое поле творческой деятельности, например, разработка Полюса Холода, а также создание серии комиксов на тему: «Чысхаан - Хранитель Холода и глобальное потепление».

На состоявшейся в декабре 2018 года международной междисциплинарной конференции «Образы Арктики» в рамках Международной триеннале современного искусства «Арктический хронотоп-2018» с участием международных экспертов из Франции, Кореи, Бельгии происходил активный межкультурный диалог между известными якутскими и зарубежными художниками, проявляющими внимание к природе и культуре Севера.

Межкультурный диалог получил свое развитие в области литературы. Так, например, в здании Генеральной Ассамблеи ООН в рамках 17-й сессии ООН по вопросам коренных народов мира состоялась презентация книги «Материальная и духовная культура народов Якутии XIX - начала XX в. в музеях мира. Сибирская коллекция в музеях США». Это первый том Системного каталога материальной и духовной культуры народов Якутии, выполненный профессором Арктического государственного 
института культуры и искусств Зинаидой Ивановной Ивановой-Унаровой.

Хотелось бы отметить, что уже несколько лет 3.И. Иванова-Унарова работает над сбором материала и составлением альбома-каталога коллекций народов Якутии в американских музеях, находящихся в Нью-Йорке, Вашингтоне и Бостоне в рамках научного проекта Академии наук РС (Я) «История Якутии».

В Варшавском университете, прошли дебаты по книге профессора АГИКИ Ульяны Алексеевны Винокуровой «Арктическая циркумполярная цивилизация». А в городе Рига (Латвия) в рамках фестиваля «Едины в многообразии» была открыта выставка якутских художников, среди которых хотелось бы назвать имена преподавателей института: Т. Шапошниковой, А. Петровой-Кэрэһит, О. Рахлеевой, С. Ивановой, Н. Николаевой, Н. Ивановой.

Институт посетили группа студентов во главе с Ацуко Сагимото, профессором университета Хоккайдо (Япония), где основан центр Исследований Арктики. Профессор Сагимото является координатором проекта «RJE-3», объектом исследований которого служит Дальний Восток и Заполярье, где в планетарном масштабе сконцентрированы такие проблемы как климатические изменения в разнообразие исторически сложившихся культур и т.д. Программа нацелена на подготовку групп специалистов, компетентных в каждой из перечисленных областей, и могущих взять на себя руководящую роль в развитии соответствующих регионов. Также прошла встреча студентов с делегацией участников Совета Правления Университета Арктики, представляющие ведущие вузы скандинавских стран (Норвегия, Швеция, Финляндия), США (Аляска) и Канады. Гости ответили на вопросы, рассказали о своих учебных заведениях, посмотрели концерт, посетили музей музыкальных инструментов Ю.И. Шейкина.

Старший преподаватель кафедры НХК, лауреат Международных конкурсов Анастасия Сидорова и студент IV курса Сергей Неустроев приняли участие в Норвегии по приглашению Университета Арктики (г. Тромсе) в проекте «Сохранение традиционной музыкальной и танцевальной культуры».

По международным программам обмена 2 студента АГИКИ проходят обучение в зарубежных вузах. Дунаева Куннэй Валентиновна, студентка 3 курса группы ДИЗ-16 направление Дизайн в рамках договора АГИКИ и
«Высшей школы искусств Рейна» обучается г. Страсбург (Франция). Лебедева Прасковья Семеновна, студентка 2 курса группы РЭКЦ-17 направление Народная художественная культура по Межправительственному соглашению с Монголией проходит обучение в Монгольском университете культуры и искусств по специальности вокальное искусство.

По программе студенческого обмена с «Высшей школы искусств Рейна» г. Страсбург (Франция) для обучения на кафедру живописи и графики, в январе 2019 года в Арктический государственный институт культуры и искусств прибыла студентка Тифайн Бранка.

Если говорить о перспективах межкультурного диалога, то на сегодняшний день вузом подписаны соглашения о сотрудничестве в сфере образования, обмена преподавателями и студентами, ведения научных проектов со следующими зарубежными образовательными учреждениями: Университет Арктики - международная организация, объединяющая более ста образовательных, научных учреждение по всему Арктическому региону. Лапландский Университет, г. Рованиеми, Финляндия, Саамский образовательный центр, г. Инари, Финляндия. Университет Кемён, г. Тэгу, Южная Корея. Монгольский государственный университет культуры и искусства, г. Улан-Батор, Монголия.

Суммируя сказанное, хотелось бы отметить, что межкультурный диалог позволяет студентам духовно обогащаться. Происходит процесс обмена информацией, именно в процессе творческой деятельности происходит формирование толерантных отношений, культуры общения и умения принять точку зрения и позицию другого.

В международной деятельности АГИКИ большое внимание уделяется программам международного студенческого обмена и взаимодействию с зарубежными учебными заведениями по профилю Института.

Развитие данных направлений является перспективным, учитывая возросший интерес студенчества и преподавателей к подобным программам, повышения мотивации участия в них и общую тенденцию повышения мобильности в современной вузовской системе, проведении совместных научно-практических конференций, обучающих семинаров, совместных мастер-классов, выставок и экспозиций.

1. Байденко, В.И. Основные тенденции развития высшего образования: глобальные и болонские измерения / В.И. Байденко. - М.: Исследовательский центр проблем качества подготовки специалистов, 2010. - С. 6-7 (352 с. 
2. Дударева, Н.А. Интернационализация российской системы высшего образования: экспорт образовательных услуг / Н.А. Дударева // Вестник ИГЭУ. - Вып. 1. -2010. - C.1-5.

3. Межкультурный диалог в условиях глобализации образования: роль вузов: материалы Международной научно-практической конференции по проблемам межнациональных отношений и международной деятельности в вузах / 16 мая 2014 г. / отв. редактор А. А. Гордиевский. — Тюмень: ТюмГНГу, 2014. $-68 c$.

4. Хорунова А.С., Пинигина 0.Н. Социально-культурная деятельность в условиях диалога культур. // Современные проблемы физической культуры, спорта и молодежи: материалы III региональной научной конференции молодых ученых, 28 февраля 2017 года / под ред. А.Ф. Сыроватской. - Чурапча: ЧГИФКиС, 2017. - С.324-327.

5. Фатхуллина А.Г. Роль межкультурного диалога молодежи в процессе творческой деятельности // Педагогическое мастерство: материалы Междунар. науч.конф. (г. Москва, апрель 2012 г.).- М.:Буки-Веди, 2012.- С.236-238.- URL https:IImoluch.rulconflpedlarchiva\22\2137\ (дата 0бращения:08.11.2019).

(с) Пинигина Ольга Николаевна (cddo@agiki.ru).

Журнал «Современная наука: актуальные проблемы теории и практики»

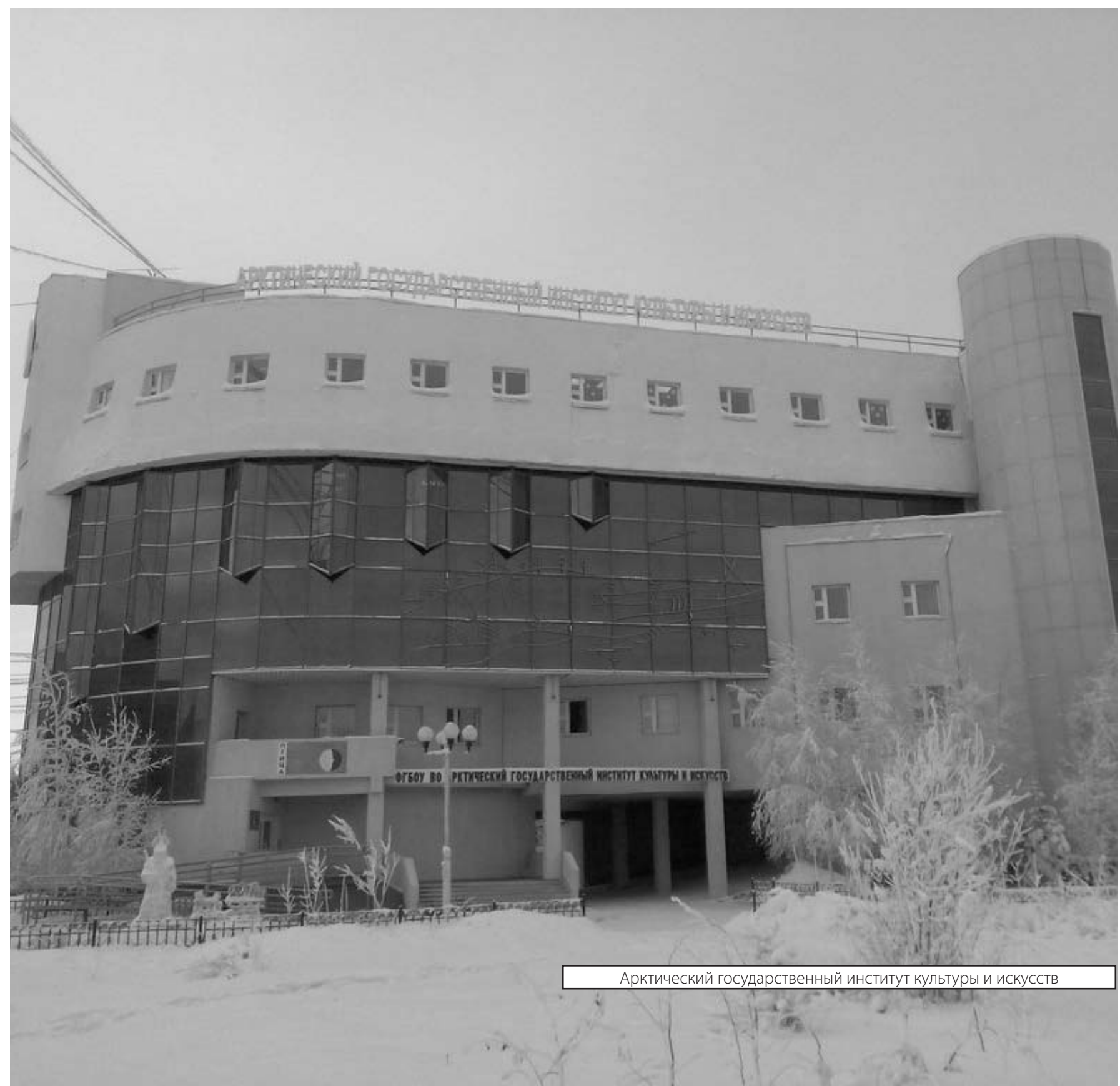

